\title{
Reflexiv internationalisering: Utvecklingsfrågor som ett bildningsområde för en folkhögskola i takt med tiden
}

\author{
Sofia Österborg Wiklund
}

\begin{abstract}
Reflective Internationalisation: Development Issues as an Educational Area for Folk High Schools in Step with the Times. This article explores discourses on internationalisation in Tidskrift för svenska folkhögskolan (Journal of Swedish Folk High Schools) between 1970 and 1989, an era when engagement for global development had become established within the Swedish popular educational system of folk high schools (FHS). The purpose is to examine what meanings are given to "internationalisation" and "the international" over time, whom and how it would affect, as well as how the FHS would engage with the issues. The study uncovers a retrospective understanding of "the international" through former nationalistic discourses as well as new postcolonial and anti-imperialist criticism. It also shows how the responsibility for development issues individualises over time. In parallel, the FHS start to work with advocacy addressing Swedish society and make the transition from seeing themselves as educators of the Global South, to expecting to become educated by the Global South. The study depict how developmental issues as an educational area continues shape the institutional identity of the FHS over time. It problematises the role of the FHS in both mobilising solidarity engagement and at the same time establishing development issues as an important area of education for the middle classes of the Global North in a society under advanced liberalism.
\end{abstract}

Keywords • internationalisation [internationalisering], folk high schools [folkhögskolor], global development [global utveckling], education [utbildning]

\section{Introduktion}

Fostran till internationell medvetenhet är något som varje folkhögskola med minsta självaktning sysslar med. (...) Termen internationell är ju i sig positivt värdeladdad och detta förstärks ytterligare genom kombinationen med sådana begrepp som engagemang, medvetenhet och andra ord som är "inne".

Utdraget ovan kommer från det tidiga sjuttiotalets Tidskrift för Svenska Folkhögskolan (TSF), en facklig tidskrift för folkhögskolans lärare och rektorer. Skribenten heter René-Harry Sülk, och är medlem i Internationella kommittén, en arbetsgrupp som arbetade specifikt med folkhögskolans internationalisering. Som citatet vittnar om är "internationell medvetenhet" en viktig aspekt att förhålla sig till i sjuttiotalets folkhögskola; det är positivt laddat, "inne" och ett måste att engagera sig i för varje folkhögskola med "minsta självaktning". Citatet är situerat i ett folkhögskoleväsende som historiskt har haft ett långtgående nordiskt och internationellt engagemang, men som relativt nyligen har svepts med i 68-rörelsen samt det institutionella biståndets expandering. Nya krafter har börjat etablera sig på folkhögskolorna, såsom rörelsen Progressiv folkhögskola som under en tid hade stort inflytande också inom

1 René-Harry Sülk, "Internationella kommittén," TSF 1972:4.

Sofia Österborg Wiklund is a PhD in Education at the Department of Behavioural Sciences and Learning, Linköping University, Sweden.

Email: sofia.osterborg.wiklund@liu.se

Nordic Journal of Educational History 2019. (c) Sofia Österborg Wiklund. This is an Open Access article distributed under the terms of the Creative Commons CC-BY4.0 License (http://creativecommons.org/licenses/by/4.0/). 
det fackliga Svenska folkhögskolans lärarförbund, SFHL. Tidsandans radikala idéer utmanade gamla dogmer inom folkhögskolan, som tidigare varit en traditionstyngd och patriarkal institution. ${ }^{2}$ Det var också under en tid då folkhögskolans plats i utbildningslandskapet var osäker och dess framtid oviss. Folkhögskolan hade konkurrens av utbyggnaden av andra skolformer och var tvungen att omforma sitt kursutbud och sin roll i samhället. Internationella "u-linjer" uppkom som några av de första särskilda kurserna vid sidan om de allmänna kurserna på folkhögskolorna och hjälpte på så sätt folkhögskolan som institution att hålla sig aktuell i sin samtid. ${ }^{3}$

Att efterkrigstiden var en omvälvande tidsperiod är såklart inte isolerat till folkhögskolan, utan präglade utbildningsväsendet, samhället och världen i stort. I Sverige utgör det en tidsperiod då det svenska internationella biståndet institutionaliserades och befolkningen mobiliserades på nationell nivå för en välvillig inställning till ett skattefinansierat internationellt bistånd, bland annat via kampanjen "Sverige hjälper". ${ }^{4}$ Tiden rör sig från sextiotalets avkolonisering och biståndsoptimism till sjuttiotalets radikala utvecklingssamarbete, samtidigt som världen befinner sig på tröskeln till åttiotalets skuldkris, strukturanpassning och nyliberalism. ${ }^{5}$

I tidigare forskning beskrivs hur denna tidsanda speglas i TSF genom att de "internationella frågorna" vuxit explosionsartat i tidskriften sedan femtiotalet, och kommit att bli näst intill synonymt med "utvecklingsfrågor". 6 Banden till den dåvarande svenska biståndsmyndigheten SIDA - Styrelsen för internationell utveckling, stärks och u-landslinjer börja förläggas på folkhögskolorna. Med hjälp av diskurshistorisk teori och metod visar tidigare forskning hur internationaliseringen förändras över tid i folkhögskolan och i TSF; från att uttrycka filantropiska, nationsbyggande och/eller säkerhetspolitiska motiv, till att allt mer betona opinionsbildning, systemkritik och anti-imperialism. Detta samtidigt som traditionella bilder av folkhögskolans uppdrag dröjer sig kvar. ${ }^{7}$

Den här artikeln bygger vidare på ovan beskriven forskning om hur "det internationella" intog TSF och folkhögskolan under 1900-talets andra hälft. Medan den tidigare forskningen fokuserar de diskurser som framträdde före och omkring uppkomsten av särskilda internationella kurser i utvecklingsfrågor, femtio- och sextiotalen, avser den här artikeln att undersöka konsolideringen av "internationalisering" och "det internationella" inom folkhögskolan under den tidsperiod som kom efter. Detta genom att studera de särskilda internationella temanummer som utgavs av den fackliga tidningen Tidskrift för svenska folkhögskolan under sjuttio- och åttio-

2 Caroline Runesdotter, I otakt med tiden?: Folkhögskolorna i ett föränderligt fält. (Göteborg: Göteborgs universitet, 2010), 163.

3 Clara Hyldgaard Nankler, Folkbildning och solidaritet: Om uppkomsten av folkhögskolans globala engagemang (Stockholm: Books on Demand, 2018), 218.

4 Se t.ex. Bertil Odén, Biståndets idéhistoria: Från Marshallhjälp till millenniemål. (Lund: Studentlitteratur, 2006); Cecilia Jonsson, Volontärerna: Internationellt hjälparbete från missionsorganisationer till volontärresebyråer. (Växjö: Linnéuniversitetet, 2012); Maj-Britt Öhman, "'Sverige hjälper:' Att fostra svenska folket till medvetenhet om sin egen storhet och andras litenhet," Tidskrift för Genusvetenskap 27, no. 1, 2008.

5 Odén (2006).

6 Sofia Österborg Wiklund, "(Inter)nationalistisk folkbildning: Säkerhetspolitik, nationalism och opinionsbildning i den svenska folkhögskolans mobilisering för utvecklingsfrågor 1950-1969," Nordic Journal of Educational History 5, no. 1, (2018), 51-72.

7 Ibid. 
talen. Syftet är att, genom inspiration av kritisk och diskurshistorisk analys, undersöka vilken innebörd som ges "internationalisering" och "det internationella" över tid, vem och vilka det skulle beröra samt hur man i tidskriften argumenterade för att folkhögskolan skulle engagera sig i frågorna. Med den kritiska blicken har jag läst materialet på jakt efter hur diskurserna förändras över tid och ger nya meningar till folkhögskolans varande i världen.

Förutom ovan nämnda artikel finns det förhållandevis lite vetenskaplig historisk forskning om folkhögskolans engagemang i globala utvecklingsfrågor samt internationalisering inom folkhögskolan. Cecilia Jonsson behandlar inte folkhögskolan specifik, men gör en analys av framväxten av folkrörelseförankrad svenskt internationellt hjälparbete generellt, samt den på senare år uppkomna volontärturismen. ${ }^{8}$ Tomasz Maliszewski berör internationaliseringen som en del i en större utveckling inom folkhögskolan ${ }^{9}$ och Katarina Leppänen studerar mellankrigstiden och de ideologiska spänningarna kring internationalism i den nordiska folkhögskolan i Genève. ${ }^{10}$ Utöver det finns texter som skrivits inom andra genrer och som behandlar folkhögskolans solidaritetsarbetes historik. ${ }^{11}$

Följaktligen finns det en lucka avseende historisk folkhögskoleforskning om internationell folkbildning som tar fasta på tidsperioden då arbetet för utvecklingsfrågor fick ordentligt fäste i folkhögskolan. På samma sätt finns det utrymme att fylla i utbildningspolitisk, historisk forskning angående hur engagemanget för utvecklingsfrågor tog sig uttryck inom folkhögskoleväsendet under sjuttio- och åttiotalen. Den här artikeln syftar således på att fylla dessa luckor.

\section{Kritiskt diskurshistoriskt angreppssätt}

I analysen av materialet har jag inspirerats av kritisk diskursanalys (CDA) och diskurshistorisk analys (DHA). ${ }^{12}$ Detta i bemärkelsen att jag bygger analysen på utvalda verktyg från dessa teoretiska ramverk, samt utgår från några av grundpremisserna för det kritiska i CDA och DHA. Dessa grundantaganden består här av ett icke-neutralt ställningstagande mot ojämlika maktförhållanden samt en blick för hur ideologi verkar i materialet. Detta innebär "to investigate critically social inequality as it is expressed, signalled, constituted, legitimized and so on by language use (or in discourse)" ${ }^{13}$ Den kritiska diskursanalysen utgår ifrån att diskurser både formar och är formade av institutioner och strukturer i ett dialektiskt förhållande mellan diskurs och det sociala. I TSF innebär det att det som uttrycks i tidskriften både är format och formar materiella och strukturella villkor. Här har jag haft ett intresse för förändring och hur diskurser bygger vidare på tidigare språkbruk, genom

8 Jonsson (2012).

9 Tomasz Maliszewski, Den svenska folkhögskolan: En betraktelse från andra sidan Östersjön. (Linköping: Vuxenutbildarcentrum, 2008).

10 Katarina Leppänen, "Education for Internationalism at the Nordic School for Adult Education in Geneva 1931-1939," History of Education 40, no 5 (2011), 635-49.

11 Se t.ex. Hyldgaard Nankler (2018).

12 Se Norman Fairclough, Discourse and Social Change (Cambridge: Polity, 1992); Martin Reisigl och Ruth Wodak, "The Discourse Historical Approach," i Methods of Critical Discourse Analysis, red. Ruth Wodak och Michael Meyer (London: SAGE, 2001), 63-94.

13 Ruth Wodak och Michael Meyer, red., Methods of Critical Discourse Analysis (London: SAGE, 2001), 2 . 
begreppet intertextualitet. ${ }^{14}$ För att studera relationen mellan biståndsväsendet och folkhögskolan har jag använt mig av verktyget interdiskursivitet,${ }^{15}$ vilket innebär att olika institutioner har olika diskursordningar där diskurser kan flöda emellan. Folkhögskolans diskursordning kan med andra ord präglas av biståndets och tvärtom.

En förutsättning för både CDA och DHA är att inkludera andra analytiska ramverk som kan ge analysen ytterligare sociala, politiska och historiska dimensioner. I det här arbetet har jag situerat materialet i sin samtid genom att förstå det som inbegripet i vad sociologen Nikolas Rose kallar "advanced liberalism" och hur samhället har gått mot att allt mer "govern through the regulated and accountable choices of autonomous agents - citizens, consumers, parents, employees, managers, investors - and to govern through intensifying and acting upon their allegiance to particular 'communities"'. ${ }^{16}$ Utifrån detta har jag lutat analysen mot "middle range theories" som gör analyser av det partikulära utbildningspolitiska samhällsläget, särskilt i Sverige och Europa, under tidsperioden, utifrån samma eller liknande idétraditioner som Rose. ${ }^{17}$ Ett sätt att styra på är just via vuxnas lärande, där styrningsmekanismerna har skiftat från att ske "ovanifrån" till att ske genom individen och dess handlingar. Genom imperativ såsom "livslångt lärande" antas Sverige som välfärdsland därmed skapa förutsättningar att stå sig i den internationella konkurrensen. ${ }^{18}$

Jag utgår teoretiskt från en förståelse av globalisering av utbildning som de ekonomiska, politiska och sociala krafter som pressar högre utbildning mot internationalisering. Internationalisering utgår jag från att vara de policys och verksamheter som används för att handskas med den globaliserande, akademiska omgivningen. ${ }^{19}$ All övrig behandling av begreppet "internationalisering" är empirisk, och jag går därmed inte in i en teoretisk diskussion av just det begreppet. Detta för att istället undersöka vad begreppet internationalisering får för betydelse i folkhögskolekontexten under den givna tidsepoken.

\section{Tidskrift för svenska folkhögskolans internationella temanummer}

Materialet består av elva internationella temanummer av Tidskrift för svenska folkhögskolan från tidsperioden 1970-1989. Fem temanummer kommer från sjuttiotalet och sex stycken från åttiotalet. Totalt utgör de cirka 150 texter i olika genrer. Jag har särskilt studerat ledartexterna, de som sätter tonen för upplagan, samt texter som gör anspråk på att förklara just internationalisering och utvecklingsfrågor i de stora dragen.

14 Se Norman Fairclough, Critical Discourse Analysis: The Critical Study of Language, 2 ed. (Harlow: Longman, 2010).

15 Ibid.

16 Nikolas Rose, "Advanced Liberalism," i The Anthropology of the State: A Reader, red. Aradhana Sharma och Akhil Gupta, (New Jersey: John Wiley and Sons, 2006).

17 Magnus Dahlstedt och Andreas Fejes, "Shaping Entrepreneurial Citizens: A Genealogy of Entrepreneurship Education in Sweden," Critical Studies in Education 60, no. 4 (2017); Andreas Fejes, "The Planetspeak Discourse of Lifelong Learning in Sweden: What is an Educable Adult?" Journal of Education Policy 21, no. 6 (2006), 697-716.

18 Fejes (2006).

19 Philip G. Altbach och Jane Knight, "The Internationalization of Higher Education: Motivations and Realities," Journal of Studies in International Education 11, no. 3-4 (2007), 290-305. 
Urvalet bygger på en större materialinsamling jag har gjort med fokus på internationalisering och utveckling i TSF mellan åren 1920 och 2015. ${ }^{20}$ Det är emellertid under sextiotalet som intresset för "det internationella" fullkomligen exploderar i TSF, och sjuttio- och åttiotalens nummer utgör ett enormt stort underlag. För att kunna göra en mer grundlig analys, istället för en överskådlig, har jag därför valt ut temanummer som behandlar frågorna. De är viktiga forum ur flera aspekter. Dels är TSF en inflytelserik arena för folkhögskoledebatt, som även studerats i tidigare folkbildningsforskning. ${ }^{21}$ Dels talar det rika omfånget av internationella temanummer under perioden sitt tydliga språk att det rör sig om viktiga frågor; elva temanummer under en tidsperiod av tjugo år. ${ }^{22}$

\section{Folkhögskolans internationalisering blir engagemang i utvecklingsfrågor}

En av de mest påfallande insikterna vid en diskurshistoriskt inspirerad läsning av TSF's internationella temanummer, är hur internationalisering, som ett nödvändigt nästa steg i folkhögskolans varande och uppdrag, nästan automatiskt får innebörden "u-landsfrågor". ${ }^{23}$ Det är med andra ord inte internationalisering i form av ökat utbyte med andra länder i det globala Nord, ökat europeiskt eller nordiskt samarbete (som ju historiskt också är viktiga områden för folkhögskolan), som står i förgrunden för vad som här klassas som det internationella, utan det är just "u-landsengagemanget". Som temanumren gör gällande är det inte främmande att med självklarhet namnge ett temanummer med något som innefattar ordet internationell och där det underförstått betyder att numret behandlar utvecklingsfrågor, och inte företrädesvis kontakter med till exempel andra europeiska länder eller USA, vilka också har varit viktiga delar av folkhögskolans internationella kontakter. Det är en inriktning som har kommit att prägla folkhögskolans mobilitet till dags dagar och som särskiljer den från exempelvis studentmobilitet $i$ högre utbildning. ${ }^{24}$

Frågan om folkhögskolans internationalisering och "det internationella" på folkhögskolan måste, menar jag, därmed också förstås som en fråga om folkhögskolans engagemang i utvecklingsfrågor och kontakterna mellan svenska folkhögskolor, biståndsväsendet och aktörer i det globala Syd. På så sätt börjar folkhögskolan inta och forma en, vad Jonsson kallar, "standardberättelse" kring svenskt internationellt hjälparbete. ${ }^{25}$ Det betyder här att folkhögskolans diskursordning blandas och skapas tillsammans med biståndets diskursordning. TSF och folkhögskolan får under tidsperioden en starkare biståndsprofil, som i tidskriftens publiceringar inte minst tar sig uttryck genom de nära kopplingarna till biståndsmyndigheten SIDA. SIDA bi-

20 Varav tidsperioden 1950-1969 utgör material för den artikel som den här studien bygger vidare på, se Österborg Wiklund (2018).

21 Se t.ex. Runesdotter, 2010; Annelie Andersén, Ett särskilt perspektiv på högre studier?: Folkhögskoledeltagares sociala representationer om högskola och universitet (Jönköping: Högskolan i Jönköping, 2011); Österborg Wiklund (2018).

22 Det finns dessutom ytterligare ett antal nummer som kan klassas som "teman i numret" snarare än temanummer i sig, men som behandlar internationella aspekter av folkhögskolan. Dessa ingår dock inte i den här studien.

23 Jfr. Österborg Wiklund (2018).

24 Erik Nylander och Song-Eeh Ahn, "Vart leder internationaliseringen?” i Lärandets mångfald: Om vuxenpedagogik och folkbildning, red. Andreas Fejes (Lund: Studentlitteratur, 2013), 209-29.

25 Jfr. Jonsson (2012). 
drog både med publiceringskostnader och/eller material till några av de internationella numren, samtidigt som det fanns interpersonella kopplingar mellan TSF och SIDA, där en del skribenter skriver i TSF i egenskap av representanter för SIDA. På samma sätt flätas biståndets och folkhögskolans diskursordningar samman i bemärkelsen att diskurser från biståndsväsendet, exempelvis det för sjuttiotalet tidstypiska nymarxistiska, och av beroendeskolan influerade, biståndskritiken präglar även TSF.

Att denna sammansmältning sker är i sig inte förvånande. I och med efterkrigstiden, då bland annat hjälparbetet institutionaliserades i Sverige och fick en egen biståndsmyndighet i SIDA, professionaliserades också det svenska internationella hjälparbetet och ett specifikt kunskapsämne uppstod, "u-landskunskapen". ${ }^{26}$ Det internationella hjälparbetet blev på så vis inte enbart frivilligarbete, utan också mer av en profession. Till denna professionalisering fick folkhögskolan en utbildande roll. En av anledningarna till att "u-linjer" överhuvudtaget startades på folkhögskolorna var att den nybildade biståndsmyndigheten SIDA valde att förlägga sina volontärutbildningar för den svenska fredskåren på folkhögskolan. De var alltså uppdragsutbildningar från SIDA och Skolöverstyrelsen, som byggde på regeringsbeslut om statligt bistånd till utvecklingsländerna. ${ }^{27}$ Anledningen till att det blev just folkhögskolan, och inte universiteten som i andra länder, anges bland annat bero på att det fanns interpersonella kopplingar mellan SIDA och folkhögskolan. ${ }^{28}$

Mot bakgrund av detta klargör jag nedan tre olika diskursiva innebörder av internationalisering och utvecklingsengagemang i TSF under sjuttio- och åttiotalet, samt hur de ändrats över tid. Jag har ställt frågor till materialet om vem och vilka det ska beröra samt hur internationalisering argumenteras för. Det första avsnittet skildrar hur internationalisering speglas retrospektivt i TSF, både genom nationalistiska och nationalromantiserande arv men också genom anti-imperialistiska, självkritiska diskurser. Det andra avsnittet belyser hur folkhögskolan, också via retrospektion, går in i ett slags postmodernt tillstånd, där "u-landsfrågorna" uppfattas som allt mer komplexa men där också det egna ansvaret och livsstil betonas istället för en kollektiv solidarisk kamp. Det tredje avsnittet problematiserar den internationella folkbildningens subjekt och hur internationalisering, i inlemmandet i folkhögskolan, blir föremål för (opinions)bildning genom att lära av "den andre", både i folkligt mobiliserande syfte och för självspegling.

\section{Retrospektiv internationalisering, nationalism och postkolonial kritik}

I det här avsnittet belyser jag hur retrospektion, det vill säga tillbakablickande, fungerar som ett sätt att argumentera för folkhögskolans internationella gärningar, samt hur detta blir ett sätt att skapa mening och uppgift för folkhögskolan i det internationella utvecklingsarbetet. Det görs både genom traditionella nationalistiska och nyuppkomna antiimperialistiska diskurser.

Tidigare i folkhögskolan och TSF's historia har internationalismen karaktäriserats av en argumentation som tar avstamp i en redan väletablerad nationalistisk och nordistisk ambition med folkhögskolans varande, inte minst som medborgar-

\footnotetext{
26 Ibid., 138.

27 Hyldgaard Nankler (2018), 223.

28 Ibid., 218.
} 
fostrande institution. ${ }^{29}$ Det är ett sätt att tala på som vissa skribenter håller sig fast vid ännu ett par år in på sjuttiotalet, parallellt med att andra diskurser växer fram. Paul Terning, sätter tonen för 1972:4 temanummer om "folkhögskolan och det internationella" just genom att åberopa de tidigare nationalistiska ambitionerna med folkbildningsprojektet. Efter att ha beskrivit både "u-landsengagemanget" och kontakterna med vuxenutbildning i Europa uppmanar han till:

\begin{abstract}
Låt oss inte glömma bort, att vi dock kulturellt sett är en del av Europa, att vi hör dit antingen vi vill det eller inte och att vi, hur mycket vi än intresserar oss för och strävar efter att nå fram till det världsmedborgerliga idealet, dock har våra rötter i skandinavisk och europeisk mark. Från det kan vi aldrig göra oss urarva. Där finns början till våra egna insatser och bidrag i internationella, världsvida insatser. (...) Viktigt är naturligtvis att vi alltmer besinnar oss på internationaliseringen av vår undervisning och det internationella i den. (...) Folkhögskolan växte fram i en nationellt betonad tid och har oftast varit nationellt och nordiskt färgad. Då den varit som bäst har den dock dessutom alltid varit öppen och haft en vid syn. Det gäller nu mer än någonsin att så vara. Låt oss inte kasta bort vare sig det nationella eller det nordiska, det hör med till vår "ursprungsmiljö" som vi aldrig kan springa ifrån utan fara. Men låt oss vara öppna också mot Europa, mot världen, för vad vi kan få och ge. I sista hand hör det med till värnet av vår frihet. ${ }^{30}$
\end{abstract}

Även om skribenten hänvisar till folkhögskolans nordism och nationalism som grund för sin internationalisering, har "hemmet" här utvidgats ytterligare. Om det på femtio- och sextiotalet argumenterades för att folkhögskolans medborgarfostrande uppdrag skulle expandera från bygden och nationen till Norden, Europa och det vidare internationella, ${ }^{31}$ har argumentationen redan här, i början av sjuttiotalet, utvidgats till att utgå från Europa. Det kan tolkas som att de diskursiva gränserna förflyttats via folkhögskolans redan etablerade internationalisering, och att folkhögskolans hemvist på sjuttiotalet inte med samma självklarhet längre hör till bygden, nationen eller regionen, utan istället hela den europeiska kontinenten vis-à-vis resten av världen. Med tiden tycks denna förflyttning expandera så pass mycket att kontrasteringen mot bygden och nationen inte längre är aktuell. Under sjuttiotalet försvinner talet om folkhögskolans nationella och nordistiska varande och uppdrag i förhållande till internationalisering allt mer, och det internationella blir en mer självklar del av verksamheterna, som står för sig självt.

En aspekt av den retrospektivt kontrasterande internationaliseringsdiskursen, som även förekom under femtio- och sextiotalen, är när skribenter relaterar de samtida utvecklingsländernas situation till det svenska samhällets historia; en allegori av "u-landet och det förflutna". ${ }^{32}$ I den jämförelsen finns en förhoppning om att folkbildningen ska kunna hjälpa utvecklingsländernas folk ur fattigdom på samma vis som den en gång, enligt narrativet, hjälpte Sverige ur fattigdom. Terning lyfter just

29 Österborg Wiklund (2018).

30 Paul Terning, TSF, 1972:4.

31 Österborg Wiklund (2018).

32 Ibid.; jfr. Johannes Fabian, Time and the Other: How Anthropology Makes Its Object (New York: Columbia University Press, 2014). 
den idén med anledning av Erica Simons, inom svensk folkbildning inflytelserika, avhandling Reveil national et culture populaire en Scandinavie. ${ }^{33}$

\begin{abstract}
Folkhögskola och folkbildningssträvanden växte fram medan de nordiska länderna ännu var u-land och har lämnat betydelsefulla bidrag till utformningen av det moderna, demokratiska och skandinaviska samhället. Det finns i vårt historiska arv, i våra ursprungliga drivande idéer något som står i samklang med dagens u-länder och deras situation. ${ }^{34}$
\end{abstract}

Detta retrospektiva angreppssätt, att snegla tillbaka i den svenska folkbildningens historia för att argumentera för och skapa mening med de nutida förehavandena, kan ses som länkade till de nationalistiska och nationalromantiska rötterna inom folkbildningen. ${ }^{35}$ Den svenska folkhögskolan gick tidigt sin egen väg, men var också influerad av det danska folkhögskolearvets nationella fostran via folkbildning, med ideologen Nikolaj Frederik Severin Grundtvig som förgrundsgestalt. ${ }^{36}$ Ur Grundtvigs skrivelser kommer också tankar om folkbildning och en gemensam nordisk identitet. $^{37}$

Åberopandet av ett folkhögskolans nationalarv sinar i debatten i TSF under sjuttiotalet, och ger plats för andra förståelser av folkbildningens varande och ambitioner. Narrativ om folkbildningens europeiska arv befästs emellertid starkt inom TSF, men inte på det sätt som Terning uppmanade till 1972. Istället formuleras det europeiska arvet som det koloniala arvet i och med att de bistånds- och systemkritiska idéströmningarna intar folkhögskolan i samband med 68-rörelsen och de avkolonialiserande kamperna världen över. Gemensamt för både sjuttio- och åttiotalens internationella temanummer i TSF är att texterna om det internationella präglas av retrospektion också i avseendet av ett kritiskt återblickande till, och omvärderande av, tidigare årtiondens internationella utvecklingsarbete. Under sjuttiotalet kritiseras femtio- och sextiotalens missionerande och filantropiska drag, och under åttiotalet läggs även sextio- och sjuttiotalets "naiva" biståndsoptimism och "förenklade", radikala analyser till granskningen. Under sjuttiotalets första hälft görs detta inte minst gällande i Paul Ternings tio sidor långa "historiska exposé" över folkhögskolans engagemang i utvecklingsfrågor (som, liksom tryckningen av temanumret, finansierats av SIDA). ${ }^{38}$ I inledningen till temanumret 1974:1, som även det understötts med material av SIDA, speglas också denna kritiska blick på folkhögskolans tidigare förehavanden. Där konstateras att "Även vi är beroende av den värld som vi tidigare med filantropisk överlägsenhet sände små nådegåvor" ${ }^{39}$

33 Erica Simons, Reveil national et culture populaire en Scandinavie, 1960.

34 Paul Terning, TSF, 1974:4.

35 Jfr. Österborg Wiklund (2018); Jfr. Samuel Edquist, En folklig historia: Historieskrivningen i studieförbund och hembygdsrörelse. (Umeå: Boréa, 2009); Henrik Nordvall, "Att bilda ett folk," i Nyttan med folklig bildning, red. Bernt Gustavsson och Matilda Wiklund (Lund: Nordic Academic Press, 2013), 34-61.

36 Maliszewski (2008).

37 Läppenen (2011).

38 TSF, 1974:4.

39 Inge Jakobsson, "Internationell medvetenhet," TSF, 1974:1. 
Under åttiotalet förflyttades kritiken till att också gälla sjuttiotalets "naiva" perspektiv på utvecklingsproblematik. Utvecklingsfrågorna uppfattas som allt mer komplexa. Margret Kihlén sammanfattar det hela kort och koncist i ett temanummer som ägnat en stor del av utrymmet åt olika folkbildares tillbakablickande perspektiv på utvecklingsengagemanget 1968 versus 1988:

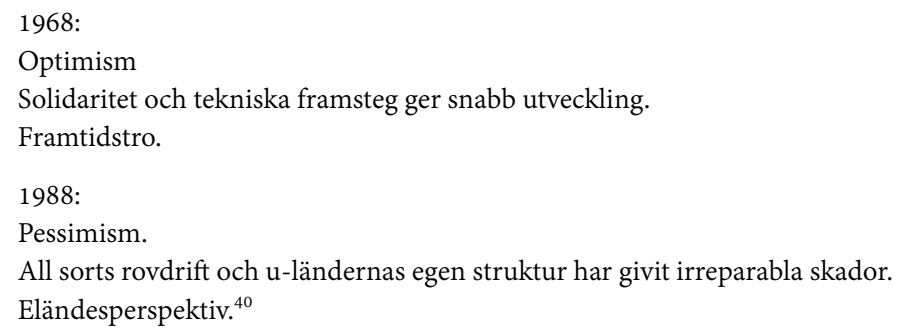

I det här avsnittet har jag lyfts fram hur internationalisering i folkhögskolan, även om den under sjuttiotalets lyfts fram som en fråga för att göra folkhögskolan aktuell i samtiden, ${ }^{41}$ och på åttiotalet som en fråga som falnat på dagordningen, skapas genom tillbakablickande. I detta framkommer också tydligt en idéförskjutning mot, inte helt oväntat, en mer individualistisk förståelse av folkhögskolans varande och uppdrag i utvecklings- och det internationella engagemanget, samt en uppfattning av frågorna som långt mer komplexa än vad som tidigare trotts.

\title{
Komplex internationalisering, eget ansvar och skuld
}

\begin{abstract}
Under 1970-talet har det allt tydligare blivit klargjort att världen inte har råd med Sverige. Nu i början av 80-talet visar det sig att inte heller Sverige har råd med svenskarna. Härmed är också sagt, att ska det bli någon förändring är det upp till var och en av oss att svara för den. ${ }^{42}$
\end{abstract}

Det här avsnittet behandlar också retrospektion, men med fokus på hur internationaliseringen går från att ses som en kollektiv angelägenhet till en fråga om eget ansvar och skuld hos skribenterna. I TSF gör olika diskurser gällande en syn som allt mer börjar se relationerna mellan "u- och i-länder" som sammanflätade och i ömsesidigt beroende. Detta i kontrast till uppfattningen av utvecklingsfrågor som något isolerat till "u-länderna" och perspektiv utifrån ett stadieutvecklingsteoretiskt tänkande.

Utvecklingsfrågorna uppfattas under åttiotalet som mer komplexa än tidigare. I TSF:s första internationella temanummer på engelska statueras det exempelvis att "A FHS (Folk High School) should, like a drop of water, be able to mirror the whole universe". ${ }^{43}$ Nya frågor, tidstypiska för periodens allmänna samhälleliga debatt, inlemmas också i förståelsen av "u-landsfrågorna" och internationalisering i TSF under sjuttio- och åttiotalen. Detta är framförallt kärnvapenhot, freds och nedrustnings-

40 Margret Kihlén, TSF, 1988:7.

41 Jfr. Runesdotter (2010).

42 Jan Lövenvald, "Aktiv solidaritet!," TSF, 1980:8.

43 TSF, 1987:8. 
frågor ${ }^{44}$ miljöfrågor, islam och feminism. Mångfalden bland skribenterna utvidgas också under tidsperioden.

Åttiotalets diskurser präglas av att det tidigare mycket "enklare", ur 68-rörelsen inspirerade, radikala engagemanget nu blivit svåröverskådligt, partikulärt och komplext. Det är situerat i en tid av ett bistånd i kris och en värld i katastrof.45 "De svåra frågorna" som de kom att kallas i den fria internationella gruppen ${ }^{46}$ beskrivs inte som svåra "i intellektuell bemärkelse" utan för att de aktualiserar "moraliska dilemman" och ett ifrågasättande av en "etablerad världsbild".47 Eller som Elisabeth Elander, Torbjörn Eriksson och Göran Sallnäs uttrycker det i TSF 1987:1: "De internationella frågorna och vårt förhållande till u-länderna har blivit allt svårare att tyda". Utvecklingsfrågornas komplexitet blev till och med utgångspunkten för en återkommande konferens för folkhögskollärare, intresserade i frågorna..$^{48}$

Det finns i TSF samtidigt en oro för att de internationella frågorna började försvinna från dagordningen i den allmänna debatten, över att deltagarunderlaget för u-landslinjerna minskade och det blev svårare att mobilisera människor i frågorna. Detta är också utgångspunkten för temanumret "Internationell solidaritet" 1988 (där också SIDA har varit med och sponsrat trycket).

Det s k u-landsproblemets eviga frågor har i olika tappningar och formuleringar följt oss folkbildare genom åren. Hur har vi svarat? Och hur svarar vi nu?

Förr var det ganska enkelt. De som var med under tidigt sextiotal och ännu tidigare hade standardsvar att ta till. (...) Efter 1968 blev det alltså svårare att svara på u-landsproblematiken "eviga frågor". (...) Den världspolitiska utvecklingen tycktes också under åren kring 1970 gå beroendeskolans väg. Men mot slutet av 70-talet hade det återigen blivit mer komplicerat. ${ }^{49}$

Vad ger vi idag för svar på "de eviga frågorna" kring u-lands problemet? Har vi idag i en värld av skuldkris och snabbt annalkande global miljökris några enkla standardsvar längre? Finns det över huvud taget några klara linjer i stil med dem som Beroendeskolan - eller före 1968 moderniseringsparadigmet - bestod oss med? ${ }^{50}$

Tidsperioden i slutet av åttiotalet framskrivs som ett slags vägskäl för engagemanget i utvecklingsfrågor. Staffan Roselius utrönar fyra olika vägar att gå, som han menar har drag av både det gamla modernitetsparadigmet och beroendeskolan. Han gör gällande att förutom nyliberalismen, har åttiotalet också präglats av en renässans för klassiskt marxistiskt tänkande, vidareutvecklingar av beroendeskolan och en för tiden ny och fjärde huvudströmning, alternativismen. ${ }^{51}$

44 Se t.ex. temanummer 1987:3 om fred.

45 TSF, 1988:7.

46 TSF, 1988:7.

47 TSF, $1988: 7$.

48 Se TSF, 1988:7.

49 Staffan Roselius, "Om utveckling och utvecklingsteorier," TSF, 1988:7.

50 Staffan Roselius, "Efter beroendeskolan-vad?," TSF, 1988:7.

51 Ibid. 
Under åttiotalet blir tonen i TSF också allt mer resignerad. Det internationella är inte bara svårt, det är näst intill omöjligt. Den tidigare kritiska hållningen, som kanske riktade in sig på en mer strukturell analys, blir mer individfokuserad, i bemärkelsen att de betonar det egna ansvaret i utvecklingsproblematiken. De internationella ambitionerna blir föremål för en slags bitterhet och skuld över sakernas tillstånd, och inte minst, folkbildarnas egna positioner i världsordningen. "Ansvar" träder fram allt mer i talet om Sverige och folkhögskolans roll i det internationella. Jan Lövenvald skriver:

Den tiden är förbi, då kollekter och insamlingar och avdelandet av ända upp till $1 \%$ av våra årligen ökande resurser av de flesta av oss ansågs som ett fullgott alibi för vårt välstånd i en värld av nöd. Vi bidrog ju ändå till en utveckling och bara vi såg till att vi fortsatte att avstå från någon liten del av vårt eget ökande välstånd så skulle tillväxten räcka åt både dem och oss. Det var ökningen vi skulle dela med oss av, självfallet var det inte fråga om att minska standarden för någon enda av oss. (...)

FOLKHÖGSKOLANS ANSVAR Jag har i ett flertal andra sammanhang hävdat, att vi som är verksamma inom folkhögskolan har ett alldeles särskilt ansvar i de här sammanhangen. Detta mot bakgrund av våra rent yrkesmässiga skyldigheter, själva vitsen med folkhögskolan som en mänsklig frigörande och därmed samhällsförändrande utbildningsform. Men också mot bakgrund av de materiellt förmånliga villkor vi har att arbeta under, såväl vad gäller resurstilldelningen till skolorna och våra jobb som våra egna lönevillkor. Vi har sedan länge tagit de internationella frågorna och den internationella nöden på allvar inom folkhögskolan. Vi har tidigt ställt upp för utvecklingsarbete och bidragsinsatser. Men vi har liksom människorna och samhället i övrigt begränsat våra insatser till en ytterst marginell del av våra ansträngningar och till att beröra bara en del av ökningen av vår standard. Vi har hela tiden spelat med på systemets villkor, våra handlingar har inte på minsta sätt varit upphävande, systemförändrande. (...) När vi nu allt tydligare ser, att resurserna är begränsade och att de omöjligen räcker att bereda vårt välstånd åt alla och när vi också inser, att vi varken maktpolitiskt eller moraliskt kan långsiktigt försvara våra överflödspositioner - kanske vi då allt flera av oss drar slutsatsen att det är vårt ansvar, mitt ansvar, att börja trappa ned på kraven. Att börja se mer på skyldigheterna än på rättigheterna. ${ }^{52}$

I Lövenvalds inlägg beskrivs en slags kollektiv, moralisk skyldighet gentemot utvecklingsländerna. Samtidigt betonar han också att "vårt" ansvar även betyder "mitt" ansvar. Vid ett annat tillfälle uppmanar Berit Brage läsarna till: "Betänk att i denna konflikt ingår du och jag och att vi gemensamt bygger delar av vårt välstånd på fattiga människors nöd". ${ }^{53}$ Att betona det individuella ansvaret, men också skulden, tolkar jag här som ett retoriskt gångbart sätt att interpellera läsaren på och som är återkommande under åttiotalet.

Eget ansvar beskrivs också som en av lösningarna på den orättvisa världsordningen. Begreppet "livsstil" dyker upp som ett sätt att bedriva engagemang för utveckling på. År 1980 redovisas en undersökning om Vallas u-linjes deltagares syften med u-linjeåret, och som betonar just den egna livsstilen.

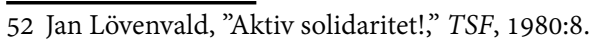

53 Berit Brage, "Varför fredskurser?," TSF, 1987:3. 
Framför allt de senare årens U-linjeelever betonar också att personlig livsstil är ett sätt att sprida opinion för en rättvisare fördelning av jordens resurser. Och därmed en handling för u-länderna. Att leva sparsamt, äta vegetariskt, bo kollektivt är också ett sätt att påverka utvecklingen. (...) Personlig frigörelse, en viktig gemenskap som räcker långt utöver $U$-linjeåret, och tilltro till den egna förmågan att göra samhälleliga insatser överhuvudtaget tycker många var det viktigaste. ${ }^{54}$

Ytterligare ett exempel på hur utvecklingsfrågorna individualiseras under åttiotalet är Bengt Erikssons uppmaning till individuell, inre revolution genom en förändrad livsstil.

\begin{abstract}
Vi måste på något sätt få ned hastigheten till en nivå där vi känner att det är vi och inte några diffusa "marknadskrafter" som har kontrollen. För att genomföra detta krävs en revolution. En revolution inom varje människa, nämligen den att ta ansvar för sina egna handlingar. Först då när vi delegerar ansvaret till kortsiktigt tänkande politiker, militärer och andra makthavare. Först då, när vi byter ut kvalitet (tillväxt) mot kvalitet (utveckling) - först då börjar de stora förändringarna! (...) Vi gör det endast genom att ta ansvar för våra egna handlingar och genom att inse att vi, varje enskild människa, i högsta grad är delaktiga i att världen ser ut som den gör. ${ }^{55}$
\end{abstract}

Utvecklingsfrågornas uttryckta komplexitet, tillsammans med det individuella ansvaret och skulden, tar sig också uttryck i en bitterhet och uppgivenhet hos det sena åttiotalets skribenter. I de retrospektiva skildringarna uttrycks tvivel om huruvida engagemanget har varit "äkta" eller enbart en putsad fasad eller en pålagd identitet från 68-rörelsen. I likhet med Berit Brage ställer sig Elisabeth Elander, Torbjörn Eriksson och Göran Sallnäs den typen av frågor 1987:

Hur ser våra relationer ut med världens fattiga? Försöker vi avhjälpa eller profiterar vi på eländet? (...) Vad innebär "internationell solidaritet"? Har uttrycket någon reell innebörd? Är det en fras, som vi använder för att försöka dölja en pinsam verklighet? ${ }^{56}$

Jan Lövenvald uttrycker tvivel angående inte bara det allmänna engagemanget i utvecklingsfrågor, utan också de egna motiven. Samtidigt använder han sig av ett retrospektivt grepp för att ställa åttiotalets livsstilsfrågor i kontrast till sjuttiotalets systemkritiska förhållningssätt, som ses som en chimär för att undvika reell förändring och avprivilegisering.

Var finns jag idag? Resignerad och trött, trött. Glöden har falnat. Och så dubbelheten i det liv som jag (och de flesta av oss) lever. (...) Och så har jag inte ens förmågan att, om än förljuget, ta tillvara och njuta allt det överflöd i olika meningar som kortsiktigt erbjudes mig, såväl som alla andra, i vår geografiska och tidsmässigt begränsade överklass. (...) Under 1970-talet fanns det en politisk medvetenhet på skolan. (...) Och många av oss utsugare stod förenade i kampen mot de större utsugarna. Sett efteråt var det mera fråga om personlig problematik och samhällelig trend än om långsiktigt betydelsefullt politiskt arbete. Och självfallet var det så mycket enklare att lägga

54 Monica Roselius, "U-linje-elevers roll i opinionsbildningen i Sverige," TSF, 1980:8.

55 Bengt Eriksson, "Vår livsstil i Sverige," TSF, 1988:7.

56 Elisabeth Elander, Torbjörn Eriksson och Göran Sallnäs, "Folkhögskolan och internationell solidaritet," TSF, 1987:1. 
skulden på kapitalet och på samhället än på den egna livshållningen och på den egna bristen på ansvar. (...). ${ }^{57}$

Ovan har jag belyst hur talet om folkhögskolans internationella arbete och utvecklingsengagemang i TSF under åttiotalet började interpellera läsarens personliga ansvar och skuld. Detta i konstrast till en tidigare mer kollektiv eller systemkritisk syn på utvecklingsproblematiken. Samtidigt blir "u- och i-landsproblematiken" sammanflätad, bilden av den globala orättvisan allt mer komplex och arbetet för global utveckling och rättvisa ses som allt mer svår och ogripbar.

I texterna tilltalas en tilltänkt läsare som förmodas kunna ställas till svars för i-ländernas oförrätter mot u-länderna. Det kan tolkas som att det är en relativt resursstark läsare som inlemmas i TSF’s "vi". Det leder oss vidare in på vem som utgör den internationella folkbildningens subjekt i TSF.

\section{(Opinions)bildande internationalisering och den internationella folkbild- ningens subjekt}

We learn about the world by going places ourselves making explorations. Our teacher
is for example an Indian beggar, a Pakistan peasant, a landlord or a minister. We learn
from them and from discussions, studying daily papers, reports and relevant litera-
ture $^{58}$

Citatet kommer från en av de första ansatserna att publicera innehåll i TSF på engelska, och därmed vidga de internationella anspråken. Citatet relaterar till en viktig del i den senare folkhögskolepedagogiken, med ideal om platta hierarkier, där var och en både kan lära och lära ut. Det skildrar tankegångar som betonar lärandet i vardagliga aktiviteter och genom att följa samhällelig utveckling i exempelvis nyhetsrapporteringar. Samtidigt ger citatet också uttryck för en tidstypisk skiftning gällande folkhögskolans roll i förhållande till det framväxande svenska internationella utvecklingssamarbetet; från att vara de (folk)bildande till att bli dem som (folk)bildas. ${ }^{59}$ Det är också här som det globala Syd tydligare framträder som, för de svenska folkbildarna, bärare av en åtråvärd kunskap som "the indian beggar", "The Pakistan peasant", "the minister" eller "the landlord" förväntas bistå med. I citatet nedan, från Paul Terning ett par år tidigare, syns denna skiftning genom att texten går i opposition mot diskursen om folkhögskolan som den givande parten:

Det kan kanske vara skäl att redan här framhålla att inte heller, då det gäller u-landsinsatser, vi har anledning att se oss som enbart givande. Det finns så mycket i den problematiken, som har värde för bedömningen av vårt samhälle, att vi även där kan vara mottagande. $^{60}$

I citatet framträder folkhögskolan ännu som den självklara givande parten, som även har något att mottaga och inte enbart är givande. Det är en diskurs som under sjuttiooch åttiotalen kom att utmanas med att istället betona nödvändigheten av perspektiv

57 Jan Lövenvald, "Från -68 till -88," TSF, 1988:7.

58 "The Travelling Folk High School in Sweden," TSF, 1978:7.

59 Österborg Wiklund (2018).

60 Paul Terning, "Folkhögskolan och det internationella," TSF, 1972:4. 
utifrån för självspegling: "We need African, Indian, or Latin American... eyes to fully see our Swedish reality". ${ }^{11}$ I och med detta skifte, som redan skedde under femtio- och sextiotalen, fick folkhögskolan en tydligare opinionsbildande roll i Sverige. Istället för att se sin uppgift som kanske framför allt folkbildande i exempelvis alfabetisering och praktiska kunskaper gentemot lokalbefolkningen i de utvecklingsländer verksamheterna bedrevs, blev folkhögskolans uppgift i TSF också inställt på att folkbilda den egna, svenska befolkningen i utvecklingsfrågor samt att väcka opinion. ${ }^{62}$

Under femtio- och sextiotalen skedde ett medvetandegörande av allmänheten nationellt i syfte att göra den svenska befolkningen välvilligt inställd till att lägga skattemedel på bistånd till andra länder. Det var ett opinionsarbete för upprättandet av ett biståndsväsende som på olika sätt var viktigt för Sveriges internationella relationer och också för dess självbild i efterkrigstiden. ${ }^{63}$ På sjuttio- och åttiotalen var biståndet mer etablerat och opinionsbildningen inom folkhögskolan fick nya innebörder. I TSF uppkommer motdiskurser mot traditionella biståndsdiskurser och allt mer postkoloniala och systemkritiska analyser av världsläget tar plats i tidskriften. ${ }^{64}$

Skiftet från hjälp till opinionsbildning, menar jag, väcker frågor om vem eller vilka som den internationella folkbildningen ska beröra. I läsningarna av TSF skildras detta både genom hur läsaren tilltalas och vem hen förmodas vara, till vem Den Andre är och hur hen beskrivs, men också genom de kritiska röster som framkommer, och vad som kritiseras, i takt med att TSF börjar att inte uteslutande publicera manliga, svenska skribenter. ${ }^{65}$ Kvinnor, ${ }^{66}$ och även i viss mån aktörer från det globala Syd, intar TSF i större utsträckning än tidigare, samtidigt som politiska ledstjärnor, kanske framför allt den tanzaniska presidenten Julius Nyerere, översätts och citeras. Under sjuttiotalet ändras också pedagogiken, och Paulo Freires tankar influerar folkhögskolan. ${ }^{67}$ TSF fick under tidsperioden en större mångfald av röster. Det är, som tidigare beskrivits, en effekt som gällde folkhögskoleväsendet i stort, som länge varit en traditionstyngd och patriarkalt styrd institution. Det var först på sextiotalet som lärare och elever på allvar hade chans att börja utmana det arvet. ${ }^{68}$ Under tidsperioden uppkom i TSF en kritik av både folkbildningen och biståndet. Marianne Mossige Norrheim beskriver det som "I-världens bistånd till u-länderna - materialistiskt patriarkalt" ${ }^{69}$

Den obehagliga upplevelsen för min del berodde på att jag tillhörde en grupp vars representation var i det närmaste obefintlig, nämligen kvinnorna. (...) Den folkhögskola som diskuterades föreföll vara en mansvärld med vanliga förtecken. Alla lärare

\footnotetext{
61 "Studies at Swedish FHS's," TSF, 1987:8.

62 Österborg Wiklund (2018).

63 Se t.ex. Öhman (2008); Per Åke Nilsson, Svenskt bistånd till den tredje världen, dess uppkomst under 1950-talet: En studie av SIDA:s och NIB:s föregångare - Centralkommittén för svenskt tekniskt bistånd till mindre utvecklade områden (Hammerdal: Hammerdal förl. och reportage, 2004).

64 Österborg Wiklund (2018).

65 Jfr. Österborg Wiklund (2018).

66 Se t.ex. TSF, 1988:7.

67 Se t.ex. temanummer om Freires pedagogik i TSF 1975:4.

68 Runesdotter (2010), 162f.

69 Marianne Mossige-Norrheim, "Utveckling för u-landskvinnor - Teori och verklighet," TSF, 1988:7.
} 
var män. Några av oss kvinnor började ta in kvinnornas situation och deras utbildning i diskussionen. Vårt initiativ fick ett blandat mottagande: från positivt stöd till avståndstagande och till och med förlöjligande. ${ }^{70}$

I det här avsnittet har jag lyft fram hur det i TSF sker en skiftning där den internationella folkbildningens manliga, västerländska dominans utmanas genom att en större mångfald av skribenter och kritik framträder. Det sker också ett skifte i vem som blir föremål för den internationella folkbildningen. TSF’s internationella subjekt går från att vara bildande gentemot utsatta grupper i utvecklingsländerna, till att vilja bli bildad av desamma. Folkhögskolan får också en allt mer opinionsbildande roll gentemot den egna, svenska befolkningen.

\section{Sammanfattande slutdiskussion}

I den här artikeln har jag undersökt vilka innebörder som ges internationalisering i TSF mellan åren 1970 och 1989, vem och vilka det skulle beröra samt argumentationer för varför folkhögskolan skulle engagera sig i utvecklingsfrågor. Resultaten får ytterligare resonans mot bakgrund av tidigare diskurshistorisk forskning om folkhögskolans internationalisering under femtio- och sextiotalen. Studien bidrar därmed med ytterligare kunskap om hur folkhögskolans internationalisering kan förstås i ett historiskt ljus.

En övergripande insikt från den diskurshistoriskt inspirerade läsningen av materialet är hur biståndets och folkhögskolans diskursordningar vävs ihop och skapas i samspel. "Det internationella" på folkhögskolorna skildras i TSF som närmast likställt med engagemang för utvecklingsfrågor. Utifrån denna förståelse av "det internationella" som "u-landsfrågor" har jag lyft fram några olika aspekter av talet om internationalisering och som jag ställer mot tidigare forskning.

Den första aspekten är att "det internationella" i TSF ofta skildras, eller argumenteras för, utifrån ett retrospektivt angreppssätt; antingen genom att knyta an till folkhögskolans och den svenska välfärdsutvecklingens historia via, inte sällan, romantiserande och nationalistiska arv, eller genom sjuttio- och åttiotalens antiimperialistiska, system- och senare också självkritiska resonemang. I det senare sättet att tala på skapas förståelsen av det samtida uppdraget och identiteten i utvecklingsfrågorna i kontrast till de tidigare, upplevda tillkortakommandena. Under sjuttiotalet kritiseras de filantropiska dragen i femtio- och sextiotalens engagemang, och under åttiotalet finns det ett avståndstagande ifrån, vad som uppfattades som, sjuttiotalets naiva världsbild. Istället betonas en förståelse av världsproblematiken, och den egna rollen i den, som mer komplex och svårhanterad. Ett självkritiskt, förbryllat och nästan uppgivet folkbildningssubjekt tar plats i TSF.

Det retrospektiva lyfts fram, och kan förstås, på ett antal olika sätt. Dels kan det förstås som ett sätt att skapa en nygammal mening av folkhögskolans förehavande i den samtida internationaliseringen, och som ett sätt för folkhögskoleväsendet att hålla sig "i takt med tiden". ${ }^{71}$ Att retrospektion användes som ett retoriskt grepp för att förstå samtiden kan ses i ljuset av att tiden runt sjuttiotalet i västvärlden generellt var präglat av ett stort folkligt intresse för släktforskning, lokalhistoria

70 Marianne Mossige-Norheim, "Kvinnorna och u-landskonferensen: En kvinnas upplevelse av folkhögskolan i utvecklingsarbetet," TSF, 1980:8.

71 Jfr. Runesdotter (2010). 
och "historia underifrån". I Sverige kanaliserades mycket av detta intresse via just folkbildningen. ${ }^{72}$ Det var ett mångbottnat intresse där radikala perspektiv underifrån flätades samman med "ett typiskt modernt sökande efter rötter i något förflutet". ${ }^{73}$ Det märktes framför allt inom vänsterrörelserna och med de emancipatoriska strävandena att förändra samhället. Ofta lyftes den moderna historien fram och hur samhället förändrats i och med modernisering och industrialism. Detta ställdes i kontrast mot forna tider, som skildrade ett Sverige i misär. ${ }^{74}$

Liksom folkhögskolans institutionella identitet i TSF skapades genom att omformulera de gamla, nationalvurmande arven i folkbildningen till att passa efterkrigstidens verkligheter under femtio- och sextiotalen, ${ }^{75}$ verkar förnyelserörelsen som präglade folkhögskolan under sjuttio- och åttiotalen följa en liknande logik. Den för folkhögskolans förnyelse viktiga rörelsen Progressiv folkhögskola, där utvecklingsfrågorna också var centrala, har i tidigare forskning lyfts fram som en aktör som lyckades vända folkhögskoledebatten just genom att omformulera gamla folkhögskolediskurser till att passa samtidens radikala tidsanda: "samma roll som tidigare historieskrivningar haft". ${ }^{76}$ Att det internationella på folkhögskolorna blev synonymt med utvecklingsfrågor kan därför ses som ett utslag av tiden och de allmänna samhälleliga strömningarna i avkolonialiseringens och sextioåttarörelsens spår, samt den tidigare etableringen av statliga biståndsorgan.

Folkhögskoleforskaren Inger Landström har lyft fram hur retrospektion, eller historicitet, kan förstås i relation till folkhögskolans självidentitet. Men hjälp av sociologen Anthony Giddens visar hon på hur den institutionella självreflexiviteten fungerar som identitetsskapande och som ett sätt för folkhögskolan att skapa strategier för framtiden, något som är särskilt tydligt vid, för skolformen, existentiellt kritiska vändningar. ${ }^{77}$ Det här materialet visar att internationaliseringen av folkhögskolan kan räknas till en sådan kritisk vändning. Det retrospektiva, såsom det framställs under sjuttio- och åttiotalens tidsanda, kan ses som ett sätt att (om)skapa en institutionell identitet, och att på så vis hålla sig "i takt med tiden"78 som utbildningsinstitution.

Att talet i TSF gick till att bli allt mer självreflexivt och retrospektivt är nära sammanflätat med hur den antikolonialt influerade kritiken också går från att vara mer systemkritisk och "kollektivistiskt" orienterad, till att under åttiotalet betona eget ansvar och skuld till de globala problemen. Samtidigt framställs frågorna som allt mer komplexa och svåra, om inte omöjliga, att lösa. Frågan om eget ansvar har studerats i utbildningspolitisk forskning och beskrivs som en nyckelkomponent i framväxten av entreprenörskap i utbildningsväsendet i bland annat Sverige. ${ }^{79}$ Här framhålls hur utbildningsdiskurser på sjuttiotalet skildrar en medborgare som ska kunna ta ansvar

\footnotetext{
72 Edquist (2009), 240.

73 Ibid., 299.

74 Ibid., 246.

75 Österborg Wiklund (2018).

76 Runesdotter (2010), 106.

77 Inger Landström, Mellan samtid och tradition: Folkhögskolans identitet i kursutbudets yrkesinriktning (Linköping: Linköpings universitet, Linköping, 2004).

78 Jfr. Runesdotter (2010).

79 Dahlstedt och Fejes (2017).
} 
för samhället och i solidaritet med andra. Detta i kontrast till senare diskurser som betonar en medborgare som tar ansvar för sig själv, sitt eget lärande och förmåga att anpassa sig till ett ständigt föränderligt samhälle; ett "entrepreneurial self" ${ }^{80}$

Kanske är det detta skifte vi kan skönja i debatterna i TSF. I skärningspunkten mellan folkhögskolans utbildningspolitiska och biståndets utvecklingspolitiska diskurser, som tillsammans tidigare skapat subjekt som framställts kämpa i solidaritet mot världens orättvisor, framträder ett subjekt som influeras av de nya individfokuserade diskurserna. Ansvaret för andra finns emellertid kvar på åttiotalet, men det finns en betoning på att det också är ett eget ansvar, i kontrast till ett mer kollektivt. Den hopplöshet och förvirring som skribenterna uttrycker inför den nya, komplexa världsanalysen, kan tolkas utifrån att de dels anammar, och dels kanske också tolkar världen utifrån en mer neoliberalt influerad världsbild och börjar ifrågasätta det egna engagemanget, och huruvida "äkta" solidaritet ens har ägt rum, utifrån det.

På liknande sätt som den globala utvecklingsproblematiken under åttiotalet allt mer blir en börda och ett ansvar för individen att bära, genomgår TSF ett skifte gällande vem som blir föremål för "u-landsengagemanget". Från att vilja bilda, modernisera och demokratisera den globala underklassen, riktas ljuset mot att (opinions) bilda och upplysa den egna svenska befolkningen och de egna leden i utvecklingsfrågor. Även detta menar jag är dubbelbottnat. Tidigare forskning gör gällande att sätten att styra genom vuxnas lärande har skiftat över tid; från att styra genom samhället till att styra genom individen och dennes handlingar. Ett livslångt lärande i befolkningen ansågs därmed som en garant för att Sverige som välfärdsstat skulle kunna hålla jämna steg i den internationella konkurrensen. ${ }^{81}$ Att utvecklingsfrågor blir föremål för bildning inom folkhögskolan kan därför förstås som en del i dessa nya imperativ av livslångt lärande och bildning av befolkningen. ${ }^{82} \mathrm{Om}$ vi tittar på tidigare forskning om volontärturism finns där liknande resonemang kring volontärerfarenhetens status som bildning. Volontärturism har beskrivits som just ett sätt för ungdomar från det globala Nord att utveckla entreprenöriella kompetenser. Det fungerar som ett sätt att "assume a type of political subjectivity that, in its fidelity to neoliberal injunctions, embodies a new normative ideal". ${ }^{83}$ Volontärturism kan därför förstås utifrån "how well it helps (re)produce subjects and social relations congruent with the logic of capital in seemingly laudable and pleasurable ways". ${ }^{4}$ På så sätt blir volontärupplevelsen "a recruitment and education strategy for young adults who need to develop the personal and professional competencies necessary for fulfilling the flexible ethos of neoliberalism".85

Folkhögskolans resandekurser är förvisso särskilda från kommersiell volontärverksamhet, men tangerar, liksom annan idéburen volontärverksamhet, samma, vad

80 Ibid., 10 .

81 Fejes (2006).

82 Jfr. Robert Aman, Impossible Interculturality?: Education and the Colonial Difference in a Multicultural World, 1. ed., PhD diss. (Linköping: Linköping University, 2014).

83 Wanda Vrasti, Volunteer Tourism in the Global South: Giving Back in Neoliberal Times (London: Routledge, 2013), 4.

84 Ibid., 4.

85 Wanda Vrasti, The Self as Enterprise: Volunteer Tourism in the Global South. PhD diss. (Hamilton: McMaster University, 2010), 99. 
Jonsson kallar, "fält" eller "standardberättelse". ${ }^{86}$ En förutsättning för att volontärarbete har kunnat bli en säljbar produkt på en marknad är just erkännande av fältet som ett viktigt "bildningsområde". Volontärerfarenheten kan generellt betraktas som ett led i en bildningsresa som har rötter ända tillbaka till de europeiska adliga ungdomarnas Le Grand Tour under 1600- och 1700-talen. ${ }^{87}$ Under senare tid har det tagit sig uttryck i både kommersiella och idéburna volontärresor, där de idéburna tillskrivs högre status på fältet. ${ }^{88}$

Med andra ord kan vi förstå skiftet mot bildningen av den egna befolkningen och folkbildarna, samt dess reflexivitet, i ljuset av hur volontärerfarenheten kan ses som ett viktigt bildningsområde i en avancerad liberalism. Bildningstanken har löpt som en röd tråd igenom folkbildningen sedan de tidiga bildningsinitiativen, och tar sig olika uttryck över tid. Folkbildningen har beskrivits som ett uttryck för en större, generell historisk strömning kring "individens roll i det kapitalistiska samhället", och har idéhistoriska rötter tillbaka till en tid där medelklassen både bildade sig själv och såg som sin uppgift att bilda arbetarklassen. ${ }^{89} \mathrm{I}$ såväl femtio- och sextiotalens som sjuttio- och åttiotalens TSF går bildningsdiskurserna från att bilda en (global) underklass till att åter röra bildandet av en (global) medelklass. Det globala Syd går därmed från att beskrivas som mottagare av folkbildning till dem som förväntas bistå med kunskap till det transnationella engagemangets "bildningsområde".

I sjuttio- och åttiotalens internationaliserande folkhögskola, situerad i en framväxande avancerad liberalism och informationssamhälle, tar denna bildning form som (opinions)bildning. Det är ett mångfascetterat koncept som både har pedagogiska och politiska dimensioner. I begreppet ligger också en idéskiftning från filantropiskt "hjälpande" till politisk påverkan. Ytterligare en aspekt rör vem och vilka som blir den internationella folkbildningens subjekt (och objekt), där marginaliserade röster tar mer plats under tidsperioden. Utifrån detta menar jag att tiden också ger uttryck för en viss pluralisering och demokratisering av engagemanget.

Resultaten i den här studien väcker frågor om vad utvecklingsfrågor, som ett viktigt bildningsområde för folkhögskolan, mer specifikt består av; vad är och har varit dess innehåll, och hur tar det sig uttryck? Hur kan det förstås ur ett postkolonialt perspektiv och vad innebär det politiskt, historiskt och socialt att globala utvecklingsfrågor blir ett bildningsområde för, specifikt, folkbildande institutioner i det globala Nord? Kommande forskning skulle förslagsvis kunna dyka djupare i hur utvecklingsfrågor som bildningsområde kan förstås utifrån fler kritiska perspektiv och med andra typer av källmaterial, såsom utbildningsmaterial eller policydokument.

86 Jfr. Jonsson (2012).

87 Jonsson (2012), 182-83.

88 Ibid.

89 Anne Berg och Samuel Edquist, "Folkbildning," i Utbildningshistoria: En introduktion, red. Esbjörn Larsson och Johannes Westberg, 2. uppl. (Lund: Studentlitteratur, 2015), 209. 


\section{Referenser \\ Tryckta källor}

Tidskrift för Svenska Folkhögskolan 1970-1989 (temanummer)

1972:4 Folkhögskolan och det internationella

1974:1 Internationell medvetenhet

1974:4 Folkhögskolan och det internationella engagemanget

1976:8 Internationalisering inom folkbildningsarbetet

1978:7 Resande och odlande folkhögskolor

1980:8 Internationellt ansvar och arbete

1984:3 Workshop -83 i Tanzania och exemplet Färneboskolan

1987:1 Tanzania

1987:3 Fred

1987:8 Like a drop of water

1988:7 Internationell solidaritet

\section{Litteratur}

Altbach Philip G. och Jane Knight. "The Internationalization of Higher Education: Motivations and Realities." Journal of Studies in International Education 11, no. 3-4 (2007), 290-305.

Aman, Robert. Impossible Interculturality?: Education and the Colonial Difference in a Multicultural World, 1. ed., PhD diss. Linköping: Linköping University, 2014.

Andersén, Annelie. Ett särskilt perspektiv på högre studier? Folkhögskoledeltagares sociala representationer om högskola och universitet. Jönköping: Högskolan i Jönköping, 2011.

Dahlstedt, Magnus och Andreas Fejes. "Shaping Entrepreneurial Citizens: A Genealogy of Entrepreneurship Education in Sweden." Critical Studies in Education 60, no. 4 (2017).

Berg, Anne och Samuel Edquist. "Folkbildning." I Utbildningshistoria: En introduktion, red. Esbjörn Larsson och Johannes Westberg, 2. uppl. Lund: Studentlitteratur, 2015.

Edquist, Samuel. En folklig historia: Historieskrivningen i studieförbund och hembygdsrörelse. Umeå: Boréa, 2009.

Fabian, Johannes. Time and the Other: How Anthropology Makes Its Object. New York: Columbia University Press, 2014.

Fairclough, Norman. Discourse and Social Change. Cambridge: Polity, 1992.

Fairclough, Norman. Critical discourse analysis: the critical study of language, 2 ed. Longman, Harlow, 2010.

Fejes, Andreas. "The Planetspeak Discourse of Lifelong Learning in Sweden: What is an Educable Adult?" Journal of Education Policy 21, no 6 (2006), 697-716.

Hyldgaard Nankler, Clara. Folkbildning och solidaritet: om uppkomsten av folkhögskolans globala engagemang. BoD, 2018.

Jonsson, Cecilia. Volontärerna: Internationellt hjälparbete från missionsorganisationer till volontärresebyråer. $\mathrm{PhD}$ diss. Växjö: Linnéuniversitetet, 2012.

Landström, Inger. Mellan samtid och tradition: Folkhögskolans identitet $i$ kursutbudets yrkesinriktning. $\mathrm{PhD}$ diss. Linköping: Linköpings universitet, 2004.

Leppänen, Katarina. "Education for Internationalism at the Nordic School for Adult Education in Geneva 1931-1939." History of Education 40, no. 5 (2011), 635-49. 
Maliszewski, Tomasz. Den svenska folkhögskolan: En betraktelse från andra sidan Östersjön. Linköping: Vuxenutbildarcentrum, 2008.

Nilsson, Per Åke. Svenskt bistånd till den tredje världen, dess uppkomst under 1950-talet: En studie av SIDA:s och NIB:s föregångare - Centralkommittén för svenskt tekniskt bistånd till mindre utvecklade områden. Hammerdal: Hammerdal förl. och reportage, 2004.

Nordvall, Henrik. "Att bilda ett folk." I Nyttan med folklig bildning, red. Bernt Gustavsson och Matilda Wiklund, 34-61. Lund; Nordic Academic Press, 2013.

Nylander, Erik och Song-Ee Ahn. "Vart leder internationaliseringen?" I Lärandets mångfald: Om vuxenpedagogik och folkbildning, red. Andreas Fejes. Lund: Studentlitteratur, 2013.

Odén, Bertil. Biståndets idéhistoria: Från Marshallhjälp till millenniemål. Lund: Studentlitteratur, 2006.

Rose, Nikolas. "Advanced Liberalism." I The Anthropology of the State: A Reader, red. Aradhana Sharma and Akhil Gupta, New Jersey: John Wiley and Sons, 2006.

Runesdotter, Caroline. I otakt med tiden? Folkhögskolorna i ett föränderligt fält. Göteborg: Göteborgs universitet, 2010.

Vrasti, Wanda. Volunteer Tourism in the Global South: Giving Back in Neoliberal Times. London: Routledge, 2013.

Vrasti, Wanda. The Self as Enterprise: Volunteer Tourism in the Global South. PhD diss. Hamilton: McMaster University, 2010.

Wodak, Ruth och Michael Meyer, red. Methods of Critical Discourse Analysis. London: SAGE, 2001.

Reisigl, Martin och Ruth Wodak. "The Discourse Historical Approach." I Methods of Critical Discourse Analysis, red. Ruth Wodak och Michael Meyer, 63-94. London: SAGE, 2001.

Öhman, Maj-Britt. '"Sverige hjälper:' Att fostra svenska folket till medvetenhet om sin egen storhet och andras litenhet." Tidskrift för Genusvetenskap 29, nr 1, (2008), 58-77.

Österborg Wiklund, Sofia. "(Inter)nationalistisk folkbildning: Säkerhetspolitik, nationalism och opinionsbildning i den svenska folkhögskolans mobilisering för utvecklingsfrågor 1950-1969." Nordic Journal of Educational History 5, no. 1 (2018), 51-72. 